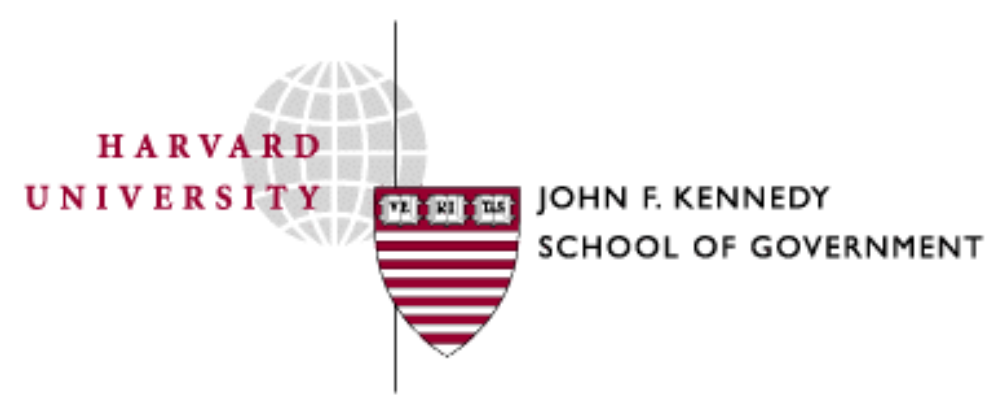

Faculty Research Working Papers Series

The Catholic Puzzle: Parishes and Civic Life

Mary Jo Bane

May 2005

RWP05-036

The views expressed in the KSG Faculty Research Working Paper Series are those of the author(s) and do not necessarily reflect those of the John F. Kennedy School of Government or Harvard University. Copyright belongs to the author(s). Papers may be downloaded for personal use only. 


\title{
The Catholic Puzzle: Parishes and Civic Life ${ }^{*}$
}

\author{
By Mary Jo Bane
}

The National Conference of Catholic Bishops issues a statement opposing stem cell research. Catholic parishes mobilized by the Industrial Area Foundations lobby for affordable housing. Lay Catholics occupy important leadership positions in local and national Right-to-Life committees. Catholic members of Congress divide, mostly but not entirely by party, in votes on partial birth abortion and on welfare reform. National polls show that neither Catholics’ demographic characteristics nor their attitudes on public issues are particularly different from the nation as a whole; and that Catholics are less involved with and give less money to religious and nonprofit groups than members of other religions. As part of their Sunday liturgies, tens of millions of Catholics hear Scripture readings and homilies urging them to eschew riches and care for the poor. ${ }^{1}$

As these examples show, the Catholic presence in American public life takes varied and often contradictory forms. The contradictions and tensions raise all manner of interesting questions and responses, for example from political strategists confused about what Catholic voters really respond to, from clergy bemoaning the fact that nobody seems to pay attention to Church teachings, and from social justice advocates wanting more involvement of Catholics individually and collectively in both national and

\footnotetext{
* This paper was prepared for an inter-disciplinary seminar on religion and American civic life that met from 2000 to 2003 under the sponsorship of Harvard's Hauser Center on Nonprofit Organizations. The paper was completed in 2004. A slightly edited version appears as Chapter 2 of Mary Jo Bane, Brent Coffin and Richard Higgins, editors, Taking Faith Seriously, Harvard University Press, 2005, pp. 63-93.
} 
international social and economic issues. My personal membership in the latter group is part of my motivation for writing this paper.

But this paper primarily reflects a more analytical stance, an attempt to engage and evaluate the Catholic presence in American civic life. As I have looked at the research on the role that congregations and other religious groupings play in shaping public life, and done some of my own, I have identified what I call the Catholic puzzle: a strong set of official teachings on social justice and faithful citizenship alongside Catholic participation in various realms of civic life that is no higher than that of other denominations, and in a number of areas, lower. Exploring this puzzle is interesting for those of us who care about the Catholic Church, but also for anyone interested in the interplay of theology, organizational forms and religious practice.

The Catholic Church and its parishes provide particularly interesting examples of this interplay. Catholics are the largest single religious denomination in the United States, with over 60 million Americans, almost a quarter of the population, identifying themselves as Catholic. ${ }^{2}$ Data on Catholics are available both from specialized surveys of Catholics and from nationally representative surveys such as the Social Capital Benchmark Survey, which I rely on in this paper, and which uses samples of Catholics that are large enough for valid analysis. In addition, because of the universal and hierarchical nature of the Church, it is possible to talk about Catholic teachings, worship and structure independent of empirically observed attitudes and behaviors, in a way that is less possible in other denominations.

There exist, therefore, a rich set of sources for understanding Catholic tradition and the practice of Catholics as they interact and play themselves out in various settings. 
They illustrate many of the complexities that Nancy Ammerman illuminates about how religious narratives influence identity and religious practice previews participation in civic life. ${ }^{3}$ In addition, as I suggest toward the end of this paper , there are also some very mundane secular realities about, for example, the size and structure of parishes, staffing and resources that influence this practice as well. Getting some understanding of all this will, I hope, illuminate both Catholic life and the intersection of religious civic life more generally.

\section{Catholic Teaching on Discipleship and Citizenship}

In Catholic theology the Church is a timeless sacrament and a global institution as well as the gathered people of God; it has a life that both encompasses and transcends the empirically observable behavior of Catholic men and women. Though Vatican II emphasized that the Church is not defined solely by its hierarchy or teaching office, the structure and nature of authority in the Catholic Church make it possible to describe its teachings, independent of the expressed beliefs and practices of its component parishes and of individual Catholics. ${ }^{4}$ My sources for this interpretation of Catholic teachings are therefore the documents of the hierarchical magisterium (the pope and the bishops), including especially the Vatican II Council documents, but also papal encyclicals especially John Paul II’s Centesimus Annus, the Catechism of the Catholic Church, and two pastoral letters produced by the National Conference of Catholic Bishops, on peace

and on the economy. ${ }^{5}$ The official documents are not completely consistent, internally or with each other, so this interpretation relies on the writings of a fairly wide range of Catholic theologians, including biblical scholars, moral theologians and ecclesiologists. 
I believe the following five propositions are contained in Catholic social teaching, accepted by the broad middle of Church leaders and theologians, and more or less reflect the official positions that the institutional Church formally teaches.

1. Christian life takes place in community, reflecting the social nature of the human person as created by God and modeled after the fellowship of Jesus and the early Church, in both small parish units and the larger Church.

Catholics believe that their relationship with God, who created humans as social beings, takes place in community. God's covenants with Abraham, Moses and David were covenants with peoples. Christian men and women belong to the community of disciples that Jesus founded and to which he continues to give life. Members of the community of disciples are called to worship and to live in a way that models for the world the values and teachings of Jesus. All are called to contribute, in various ways, to evangelization, proclaiming the good news and inviting others into the community, and to the healing and liberating work of Jesus in the world.

The parish is the primary local community in the Church, the place where disciples come together to live out their faith, and for which all have responsibility. At the same time, each parish is part of a larger community of communities, bound together by faith and the notion of discipleship itself. ${ }^{6}$ Church structures and leaders shape, promote and challenge discipleship, and through worship, reflection and renewal keep it true to Church faith and responsive to the contemporary world.

2. All believers, clergy and lay, are called to discipleship and to holiness, to participate in the community of disciples that is the Church and to contribute to the mission of the Church.

Traditionally, and reflecting an institutional and hierarchical conception of the Church, a clear distinction was made between what was expected of Catholic clergy and 
what was expected of the laity. Christian living for the laity meant avoiding sin by obeying the commandments and the teachings of the Church. Perfection and holiness were to be pursued by a decision to leave the secular world and enter the priesthood or consecrated religious life, to live by the evangelical counsels of poverty, chastity and obedience.

Vatican Council II asserted in contrast that all the faithful, laity as well as clergy, are called to a vocation as Christians of hearing and accepting Jesus' call to discipleship and of shaping their lives in accordance with that call. ${ }^{7}$ This new understanding of Christian life also requires attention to social structures and to social justice, themes that permeate a number of Council documents. ${ }^{8}$ Sin is breaking the covenant of love with God and with each other. Sin always results from individual decisions and actions, but these can result in sinful structures, social, political or economic institutions that oppress, violate human dignity or inhibit full human development. Individuals are responsible if their own actions or failure to take action contribute to the creation or maintenance of “social sin.” Lay Christians especially have a responsibility to work for justice and peace in the world, to sow the seeds of the kingdom of the God.

3. The mission of the Church encompasses salvation and liberation, this world and the next, evangelism and service, both to fellow Christians and to "all nations."

On first reading, two of the most important Vatican Council documents, both of which are elaborated in later writings and embodied in liturgy and practice, appear to take quite different positions on the mission of the Church. The first, Lumen Gentium (Dogmatic Constitution on the Church) ${ }^{9}$, articulates a predominantly otherworldly and evangelical sense of the Church. The Church was established to bring all people to belief 
in God and in the saving power of Jesus Christ, and through faith, the sacraments, and holy lives, it was bring them to eternal union with God. Holiness is primarily an interior state, characterized by prayer and a humble and loving attitude toward the world. This aspect of the mission of the Church dominates the Catechism, which devotes the vast bulk of its pages to doctrine, the sacraments, prayer, the beatitudes and the commandments.

The second document, Gaudium et Spes (Pastoral Constitution on the Church in the Modern World), is quite different. This document focuses on "the joys and the hopes, the grief and anguish of the people of our times, especially of those who are poor and afflicted."10 It talks in strong and compelling terms about human dignity and social justice, and about the responsibility of the Church for the liberation of humanity, both from personal sin and from oppressive social and economic conditions that prevent men and women from achieving their full human potential. Gaudium et Spes applies biblical and Church teaching to such contemporary issues as protection of marriage and the family, economic development, political participation and respect for diverse cultures. These issues are accorded less prominence in the Catechism, but appear even there, and are elaborated in both papal writings and documents from bishops' conferences after the Council.

A faithful reading of both contemporary and traditional Church teaching, and of the Scriptures, it seems to me, is that Christian faith is about both this world and the next, both personal holiness and social liberation, both relationship to God through worship and sacrament and ministry to the poor and marginalized. The importance of both poles of these dimensions was emphasized at Vatican II and in the subsequent writings of the 
Pope, the bishops, theologians and commentators. It was stated particularly eloquently

by the 1971 Synod of Bishops in Justice in the World:

"The Church has received from Christ the mission of preaching the Gospel message, which contains a call to man to turn away from sin to the love of the Father, universal brotherhood, and a consequent demand for justice in the world."

There are tensions and differences in emphasis on one or the other in different writings and in the worship and activities of different parishes. Nonetheless, the mission of social justice is clearly critical to the Church.

4. In community and in service, the Church has a special place, a "preferential option," for the poor and the vulnerable, as part of a consistent ethic that is prolife, pro-family and pro-poor.

Catholic social teachings begin with basic moral principles, derived from Scripture and from rational analysis, that provide the foundation for discussions of social justice. ${ }^{12}$ The American bishops' letter on the economy formulated the basic principles in the following terms: primacy of the principle of human dignity; necessity to realize human dignity in community; right of participation; obligations to the poor and vulnerable; responsibility of society as a whole to enhance human dignity and protect human rights. The bishops emphasize the special claim that the poor and the vulnerable have on the community as a whole. ${ }^{13}$

The basic principle of human dignity is also foundational to Church teaching about the preciousness of life. The fascinating thing here is that the teachings on life, on the family and on social justice all flow from an integrated analysis of the human person, the person in community and the person in relationship to God. Church teachings are indeed pro-life, pro-family and pro-poor. ${ }^{14}$ 
5. Christians are called to be responsible citizens and to participate in civic and political life to promote justice and protect life. This responsibility applies to individual Christians, to congregations and to the institutional Church.

Much religious writing and talk about the obligations to the poor conclude with recommendations that Christians experience a change of heart, love one another, take personal responsibility, and exercise private charity. ${ }^{15}$ The assumption seems to be that if business people, public officials and private citizens simply thought and behaved generously and lovingly toward each other, and if all exercised their responsibilities to themselves and each other, all would be well and the problems of poverty and injustice would disappear.

Catholic social teaching, in contrast, has both a stronger sense of sin and a more sophisticated understanding of the importance of the state, especially of democratic politics, in dealing with social and economic problems. The American bishops' letter clearly recognizes that private charity alone is not sufficient to counteract the "structures of sin” that lead to poverty and oppression. Governments are necessary inventions to mobilize collective resources and effort for the common good and the good of the less fortunate. Christians carry out their responsibilities to the poor both through individual acts of charity and through exercising responsible citizenship in the service of justice. ${ }^{16}$

More recently, the Catholic bishops have elaborated on these issues in a letter on "Faithful Citizenship,"17 which they produce every four years, before presidential elections. In this letter they say:

"In the Catholic tradition, responsible citizenship is a virtue; participation in the political process is a moral obligation.” All believers are called to faithful citizenship, to become informed, active and responsible participants in the political process." 18 
The bishops in this letter especially emphasize the responsibility of Catholics to "measure all candidates, policies, parties and platforms by how they protect of undermine the life, dignity, and rights of the human person, and whether they protect the poor and vulnerable and advance the common good."19

Are Catholic teachings unique? The "puzzle" I explore in this paper is about the thinness of Catholic civic life in the light of strong teachings on community and social justice. My framing of the puzzle asserts that Catholics ought to show more civic commitment than members of other religious traditions; this assertion presupposes a lack of equally strong social teachings by those traditions.

There have, of course, been many strong social justice statements by Protestant denominational leadership groups, and by influential theologians and pastors from many groups. There is one sense, however, in which Catholic social teachings are clearly unique. Only the Catholic Church has a teaching office, exercised by the bishops, which is unified and presumed to be binding on the faithful. The existence of the teaching office, as part of the hierarchical structure of the Church, means that Catholics should, in theory, receive consistent messages from their pastors in line with official teachings. No such structures exist in other denominations.

What happens in practice, in the hundreds of thousands of pulpits from which religious leaders preach, is another matter, about which there is precious little information. As I will argue later, there are reasons to believe that the preaching that Catholics actually hear is less sharp than the strength of the official teachings might lead one to expect. And there is much evidence that the social and political opinions and attitudes of Catholics are only slightly more pro-poor or pro-government than those of 
others. ${ }^{20}$ Nonetheless, the presence of strong official teachings in a hierarchically structured Church is sufficient, I believe to pose a puzzle worth exploring, a puzzle that existed prior to and independently of the clergy abuse scandal of 2002 and its aftermath.

\section{The Civic Life of Catholics}

The social teachings, then, are a strong set of statements about the importance of community, about responsibilities to the poor and vulnerable, about structural as well as personal sin, about the importance of faithful citizenship as well as personal charity, and about the obligations of all the faithful as members of the community that is the Church. One might expect, consistent with these teachings, that Catholic men and women would be seriously involved in community and civic life, in service and in political activity, more involved, one would think, than members of denominations with less well developed and articulated official social teachings. ${ }^{21}$

A number of studies suggest that this is not the case. A study by Independent Sector found relatively low levels of volunteering and financial contributions among Catholic respondents. ${ }^{22}$ Smith, in a study focused on evangelicals, reported that Catholics scored lower than either evangelicals or mainline Protestants on four of seven measures of social and political activism. ${ }^{23}$ Wuthnow, in a study focused on mainline Protestant church members, found that Catholics scored lower than mainline Protestants on nine measures of civic activities and lower than evangelicals on seven of the nine measures. $^{24}$

Ammerman explores the religious correlates of "doing good" in the community being involved with neighbors, volunteering for service organizations, and contributing to 
secular charities. ${ }^{25}$ She finds that among the churchgoers she studied, these civic activities are enhanced both by particular religious orientations; i.e., what she calls Golden Rule and Activist orientations rather than an Evangelical orientation; and by participation in religious activity and organizations. The patterns are interesting. Evangelical churchgoers tend to be less oriented toward broad social justice issues, but they are also extremely active in congregational life and other religious organizations. This explains, according to Ammerman, a level of civic activity among conservative Protestants that is lower than that among liberal and African American Protestants, but about equal to Catholics. Catholics, in contrast, are more likely than any group to have an activist orientation toward the world, but much less likely to actually participate in parish and other religious activities; the Catholics Ammerman studied display lower levels of civic activity than those of liberal and African American Protestants. Ammerman suggests a solution to what I have called the Catholic puzzle by pointing to the low levels of activity in Catholic parishes.

In the previous section, I described the social teachings of the Catholic Church, which reflect all three of Ammerman's orientations, but surely emphasize both private charity and civic activism. In this section, I present data from sources that complement Ammerman's and support her general findings. In the following sections I explore the next level of the Catholic puzzle: why is there so little activity in Catholic parishes?

I looked at data on civic activity from the Social Capital Benchmark Survey, a nationally representative survey of about 3000 adults conducted in fall 2000 under the leadership of Robert Putnam of Harvard and Bowling Alone fame. The survey asked an extensive series of questions about organizational memberships, community engagement, 
volunteering, giving and political activity, aimed at understanding social capital in the broadest sense. As such, it represents the best large scale source of data on many of the elements of faithful citizenship as outlined above: service to the poor and vulnerable, participation in community life and participation in electoral politics. It also asked about religious affiliation and religious activity, and included a large enough sample of Catholics to permit comparative analysis.

In this study, religious identity was established by asking respondents their religious and denominational preference. Catholics for the purposes of this analysis are all those who identify themselves as Catholic; they are not necessarily churchgoers, as are the respondents in Ammerman's study. The advantage of this study is that its Catholics are a nationally representative group, not limited to the two Albuquerque parishes studied by Ammerman.

I looked at the following measures of civic activity, several of which are constructed from a number of variables:

- Volunteering for the needy: a yes answer to a question on whether the respondent had volunteered to help the needy or elderly at any time during the past year.

- Any non-religious volunteering: a yes answer to questions on volunteering for the needy, for culture/arts, health, neighborhood or civic groups, youth or school groups.

- Contributions to non-religious charities: whether contributions were at least $\$ 100$ for the year.

- Number of formal group involvements, excluding Church and religious groups: constructed from answers to individual questions about different types of groups; e.g., sports clubs, youth organizations, school organizations, veterans groups etc.

- Electoral politics scale: constructed from questions on voting, being registered to vote, interest in politics and national affairs, political knowledge and reading a daily newspaper. 
- Protest scale: constructed from questions on belonging to any group that took local action for reform, attending a political meeting, rally, demonstration or march, signing a petition, participating in a political group, an ethnic nationality or civil rights organization or a labor union.

I also looked at one measure that combined religious and civic activity, and four

measures of religious participation:

- Giving and volunteering summary index: constructed from questions on the amount of volunteering and on contributions, both religious and non-religious.

- Whether attended religious services at least weekly.

- Any participation in Church activities besides services.

- Whether volunteered for religion.

- Contributions to religion: whether contributions for the year were at least \$100.

Table I shows the results, with means reported by three categories of religious affiliation. Religious affiliation is divided for these analyses into Catholics; those of other religions i.e., those who identify themselves as Protestants, other Christians (many of these "just Christians") or affiliates of another religion; and those who describe themselves as having no religion. I grouped together all other religions to make the contrast with Catholics clearer, but also because many of the categories, like “just Christian” were difficult to categorize more exactly. The table shows sample means, not controlling for demographic or other variables. 


\section{Table I}

\section{Civic Participation by Religious Affiliation}

Volunteering for the needy

Any non-religious volunteering

Contributions to non-religious

charities at least $\$ 100$

Number of formal non-religious

group involvements

Electoral Politics Scale

Protest Scale

Giving/volunteering summary index

Church attendance at least weekly

Any participation in Church activities other than services

Volunteered for religion

Contributions to religion

at least $\$ 100$

Source: Social Capital Benchmarks Survey 2001

\section{Catholic}

.29

.46

.43

.45

.41

2.83

3.17

2.48

2.77

3.00

2.32

.98

1.05

1.05

4.89

5.56

2.92

.48

.52

.00

.33

.50

.00

.28

.33

.00

.56
.15

The table shows a quite consistent pattern. In all cases reported participation of Catholics is lower than that for those describing themselves as members of other religions, but higher than that of those who reported no religion. Catholics were less 
likely than other religions to volunteer, to contribute to secular charities, to belong to formal groups, to participate in electoral politics or to engage in political activism. The differences in civic participation are in some cases not large, but the negative signs are consistent. With regard to participation in religious organizations, activities and giving the differences are much larger.

I then analyzed the data on informal social interaction, non-religious volunteering and contributions to non-religious charities controlling for age, gender, education, race, income, whether married and presence of children in a regression equation which also included variables for Catholic and no religious affiliation. ${ }^{26}$ With the demographic controls included the coefficients on Catholic affiliation were statistically non-significant. In all cases, those with no religious affiliation were significantly lower than other religions. ${ }^{27}$ In short, the data from the Social Capital Benchmarks Survey shows that Catholics are not more likely than adherents of other religions to volunteer, to contribute, or to participate in civic or political life.

The Social Capital Benchmark Survey does not allow for construction of the virtue orientation scales that Ammerman used to explore the ways in which religious orientation interacts with civic participation. It does, however, include information on participation in religious activities, which as shown above, indicates that Catholics are noticeably lower than other groups both in participation in activities other than services and in financial contributions to religion.

Following the logic of Ammerman's analysis, including a religious participation variable in the analyses should show a strong positive relationship of that variable with informal social interaction, non-religious volunteering and non-religious giving. 
Including a religious participation variable would also be expected to result in a positive sign on the variable that indicates whether a respondent identifies as Catholic. With religious participation controlled for, this "Catholic" variable should be representing to at least some extent the Golden Rule and Activist orientations that Ammerman found to contribute to civic involvement. This is indeed what happens, although only for nonreligious giving does the effect of being Catholic reach statistical significance. ${ }^{28}$

The simple means and regression results presented above are thus consistent with Ammerman's basic story, and suggest that it is applicable to self-identified Catholics nationwide. Broadly speaking, the Catholic story encourages community and civic participation and service to others. But Catholic parishes do not provide the opportunities and settings for practicing these virtues. Catholics, as a result, are no more likely than those of other religions to carry a service and civic involvement mission into the world. I now look more closely at the Catholic parish life that seems so crucial to this pattern.

\section{Catholic Parish Life}

Congregations are places where people come together, converse, interact, engage in projects and form bonds of cooperation and trust--social capital in short, perhaps half the social capital that exists. ${ }^{29}$ They are training grounds for civic skills—-participating in meetings, writing letters, planning projects, making decisions, giving speeches. And as Sidney Verba et al have pointed out, they are for many people, especially low income people, minorities and women, the primary setting in which these skills necessary for civic life are learned and practiced. ${ }^{30}$ The extent to which parishes teach skills, build 
networks and shape patterns of participation or fail to do so can have a powerful influence on the civic behavior of Catholics.

St. Williams's. ${ }^{31}$ My own (former) parish provides an example of a Catholic parish which, if not strictly representative, is typical of many parishes. ${ }^{32}$ St. William's serves a territory of about one square mile in north Dorchester, part of the city of Boston. The neighborhood is an old Irish enclave, heavily Catholic, which is increasingly home to immigrants, especially from Vietnam. It is mostly working and middle class, with some professionals, some subsidized housing for the elderly and families, and some poor, especially among the immigrants. Mass attendance on a typical weekend is about 1500, spread among one Vietnamese (by far the largest attendance) and four English Masses.

The parish budget is about $\$ 400,000$ per year. Both the percentage of parishioners who contribute and the percentage of income given by those who do contribute are estimated to be quite low. ${ }^{33}$ The parish has no endowment, and almost no funds set aside for contingencies; finances are very tight and a continual source of concern. The parish runs a school for about 240 children, financed by tuition, a humungous bingo game and some tuition scholarship funds from the archdiocese. The staff of the parish includes two priests, one of whom is Vietnamese, a secretary, a parttime business manager, a youth minister, and some additional paid part-time help. Two older priests who are retired from active parish work assist with weekend liturgies. The parish makes extensive use of volunteers for support of basic programs and services; over a hundred volunteers serve in one capacity or another.

The parish's mission statement, a product of the parish council, is printed every week in the bulletin and reads as follows: 
"Gathered in common praise and worship of God, we the community of St. William's Parish affirm Jesus as the center of our lives and the reason for our being. Thankful for God's goodness, we live as generous stewards of the gifts of time, talent and treasure entrusted to us. We promote unity within our parish and celebrate the richness of our diverse culture. We are and we minister to people of all ages. We are committed to excellence in our school and religious education programs. We work with others to address the concerns of the wider community and the needs of all our brothers and sisters. With God's help we strive to live out these gospel ideas, in this place, in these times."

The pastor places a good deal of emphasis on liturgies and homilies. Homilies generally reflect on the day's scriptural readings, and attempt to convey both a sense of God's love and graciousness and some practical lessons for daily life. For example, the homilies for the first weeks of ordinary time in 2000 reflected on the first few chapters of the Gospel according to Mark or Paul's first letter to the Corinthians. One spoke strongly about the need for repentance and conversion, using as examples people who changed their lives by overcoming alcoholism or devoting more time to their families. Another talked about reducing anxiety and stress through prayer and through experiencing and accepting God’s love. A third reflected on Jesus' ministry of healing and our call to be healers in our daily lives. The pastor from 1996-2003 delivered occasional homilies on social justice, including quite specific homilies on campaign finance reform and on a ballot initiative to cut taxes, both in summer and fall 2000. In the spring of 2002, the pastor preached a number of times on the crisis in the church. A new pastor came to the parish in 2003; he seems not inclined to speak to social or political issues.

Music at liturgies is quite professional, with a good choir and desultory congregational singing. Liturgies on the major feasts are bilingual in English and Vietnamese, as is a fall multi-cultural celebration. There are strong religious education programs, in both English and Vietnamese, and a small program for adults who want to 
become Catholics. The parish sponsors sports teams and hosts AA meetings; it also sponsors a parent-to-parent group. It has a committee for service to the poor, which has attracted a small number of volunteers for service at a homeless shelter. A group of parishioners and the pastor participated in two work retreats in Haiti, which other parishioners support through donations of cash, medical supplies and school supplies. The parish is a member of the Greater Boston Interfaith Organization, and some parishioners are part of that group's organizing efforts for improved education and affordable housing. During the summer and fall of 2000 the parish made voter registration available in the Church. There is a reasonably active parish council and a finance council, in addition to various ad hoc committees to plan, for example, a $75^{\text {th }}$ reunion for the parish and school, and renovations to the church.

The pastor from 1996 to 2003, who is in his mid 40s (young for a pastor; indeed young for a priest these days), was quite liberal, both politically and theologically. The parishioners are a mixed lot. The Vietnamese immigrants bring with them a conservative culture and attitude toward church. The English-speaking parishioners are quite diverse, but many combine old line conservative Democratic party politics with an approach to Catholicism that has its roots in the pre-Vatican II Church. The neighborhood is very active politically, with high voter turnouts and a strong civic association that deals with such local issues as crime, traffic and the condition of the subway stop. The changing demographics of both neighborhood and parish introduce some interesting class and ethnic diversity that the parish is dealing with; it is clearly a more diverse congregation than it has been in the past. I am an active member of the parish, and thus not an 
unbiased observer, but it seems to me a warm and lively community, supportive and not particularly demanding, that is also, in many ways, profoundly ordinary.

Patterns of parish activity. ${ }^{34}$ As at St. William's, the basic connection that most Catholics have with their parishes is through Sunday worship services. (I examine the character of worship services in the next section.) Most parishes celebrate four or five weekend liturgies. In the National Congregations Study, the median parish reported holding 11 worship services over the course of the week, including weekend liturgies, weekday Masses, funerals and weddings. ${ }^{35}$ All parishes also celebrate the other sacraments: baptism, confirmation, reconciliation (confession), marriage and anointing of the sick. These worship services and sacraments take up a good deal of the time of the ordained staff. ${ }^{36}$

In addition to liturgies, parishes sponsor a myriad of activities, the majority of which appear to be directed at the parish membership itself, both to educate members and to build community. Examples are religious education classes for children and adults, study groups, community social events and the still common bingo games.

The National Pastoral Life Center did surveys of parish staffs in 1992 and 1997 and as part of the surveys collected information on parish activities. ${ }^{37}$ Nearly all had religious education activities in both years. In 1997, 84 percent (down from 90 percent in 1992) reported having picnics, potlucks or social events for the whole parish. Thirty percent had bingo games. (The 1992 survey reported 56 percent with bingo. The change may well represent a real decline.)

The National Congregations Study asked a series of questions about congregational activities in their survey of congregational leaders. In addition to the 
median 11 worship services per week, the median parish reported sponsoring 12 classes, 5 group and 5 committee meetings over the course of a month. Respondents were also asked a series of 27 questions about specific non-worship activities. At least a quarter of the Catholic parishes responding to the survey (weighted by size) reported having a "group or meeting or class or event” devoted to: discussing a book other than the Bible (33 percent), discussing parenting issues (68), physical healing (55), cleaning or maintaining the building (66), organizing or encouraging volunteer work (75), learning about their own tradition (73), informing new members (83), prayer (86), putting on a performance of some type (51), attending a performance (40), training religious education teachers (80), learning about other religious traditions (28), twelve-step or selfhelp groups (46), or discussing congregational finances (58).

The National Congregation Survey also asked about social services programs. Mark Chaves et al report that 82 percent of Catholic parishes report participating in some kind of social service, community development or neighborhood project. These include food programs (59 percent), housing (33), clothing (19), helping the homeless (17) and health care (14).

Politics are also present. Chaves reports that in 45 percent of parishes people were told at worship services about opportunities for political activity and that 26 percent had ever distributed a voter guide. ${ }^{38}$ Some parishes, including my own, are engaged in community organizing activities, often under the auspices of the Industrial Areas Foundation. These groups, such as Greater Boston Interfaith Organizing, communities Organized for Public Service (better known as COPS) in San Antonio, and South Bronx Churches, are ecumenical, congregation based organizations, often involving dozens of 
congregations and tens of thousands of participants. They tend to focus on local issues, and have been quite successful in pressuring local officials to develop, for example, affordable housing or build water systems. ${ }^{39}$ Many observers consider these organizing efforts among the most promising in the country. ${ }^{40}$

Parishes, of course, vary enormously. My own parish of St. William's, described above, is moderately active for a parish of its size. Others are both larger and more active. In 1993, a reporter for the Long Island newspaper Newsday looked for a lively Long Island parish to serve as the focus of a series. He found St. Brigid's, which he described as "nothing like St. Rigid's” (his fictive name for lifeless and rule-bound parishes). ${ }^{41}$ St. Brigid's is a large, diverse parish of about 23,000 Catholics, four priests and five deacons. The parish, according to Keeler produces an astounding level of activity—as reflected in a Sunday bulletin that often runs twenty-two pages, compared with four to eight for the average parish. On one typical Monday evening, the peace and justice committee and the program for bringing adults into the Church met; the rock band and the children's choir practiced; boys played basketball; the church itself had an Italian mass and a candlelight rosary; and the Haitian community offered religious education. ${ }^{42}$

But despite the diversity, and despite what appears to be a fairly high level of activity in most Catholic parishes, the National Congregations Study shows that when compared with Protestant congregations of similar size, especially Evangelical congregations, Catholic parishes are much less active. Catholic parishes, relative to other congregations, are very large and appear to have a great deal going on. To understand patterns of activity more clearly, we need to adjust for size. I looked at all the congregations in the national study that reported having at least 1000 regular participants: 
for Catholics, 203 parishes, for evangelical 72, and for mainline 42 congregations. There were only 7 large black Christian congregations in the sample, so I exclude their data. These data were collected on congregations, normally through reports by the pastor or leader of the congregation. Table 3 shows some of the more interesting comparisons:

\section{Characteristics of Large Congregations by Denomination}

$\begin{array}{lll} & \text { White } & \\ & \text { Conservative// } & \text { Liberal/ } \\ \text { White } & \text { Evangelical } & \text { Mainline } \\ \text { Catholic } & \text { Protestant } & \text { Protestant }\end{array}$

Regular participants

2500

1900

1900

Number of worship services

14

3.5

3

Number of participants in more

than one worship service

70

300

25

Number of classes

14

25

23.5

Number of adults

participating in classes

30

400

100

Number of choirs

3

6

6

Number of participants

in choirs

40

120

125

Number of groups

7

13.5

13.5

Number of participants

in groups

130

400

300

Number of persons

in leadership roles

100

225

180

Number of volunteers for

social services programs

40

32.5

100

Income

$\$ 671 K$

\$1600K

$\$ 1000 \mathrm{~K}$

Full time staff

8

20

9

Source: National Congregations Study, 1999 
Large Catholic parishes are much larger than even large Protestant congregations. They also have a much larger number of worship services per week, an average of fourteen compared to about three for other denominations. (Parishes have one or two Masses on weekdays, and an average of four Masses on weekends.) Interestingly, however, they have a much smaller number of participants in more than one worship service than evangelical congregations—70 compared with 300. (Most parishes have a small but regular daily Mass crowd.)

Looking at activities other than worship services, we see that Catholic parishes have a smaller number of classes, choirs and groups, and a much smaller number of members reported participating in the these activities. They also report a much smaller number of people in leadership roles. (The same patterns appeared when I constructed per capita variables on these same dimensions and analyzed the whole sample.) The only category for which Catholic parish participation appears to be higher than for conservative Protestants is for volunteers for social services or community programs, but even here the per capita number is slightly higher for conservative and much higher for mainline Protestants.

Associated with these differences in activity are large differences in resources. The median Catholic large parish (which, remember, is considerably larger than the large Protestant congregations to which I compared them) reports annual income of $\$ 671 \mathrm{~K}$, compared with $\$ 1600 \mathrm{~K}$ for white conservative/evangelical Protestant congregations and \$990K for large white liberal/mainline Protestant congregations. The median Catholic parish reports 8 full-time staff, compared with 20 for conservative/evangelical and 9 for 
liberal/mainline Protestant congregations. Whether lower resources cause the lower levels of activity or vice versa (or neither) is an interesting but unanswerable question.

What all this suggests, I think, is that if congregations are schools for citizenship through their community life, Catholic parishes are not doing a very good job in providing this education. Why not? One possible answer is that community, service and citizenship are not really core to the mission of the Church; I examine that argument in the context of worship in the next section. I then look at some of the organizational features and constraints of Catholic parishes that shape their ability to carry out their mission.

\section{Catholic Sacramental Life}

It is certainly misleading to think of any church as a social service agency or a community organization. In describing the Church, the important Vatican II document, Lumen Gentium, describes it first as a mystery and as a sacrament—“a sign and instrument of communion with God and of the unity of the entire human race” with the mission of "proclaiming and establishing among all peoples the kingdom of Christ and God.” The Catholic Church is a sacramental church, with the Eucharist at its center.

But seeing the sacramental nature of the Church as inconsistent with teaching and practicing community and social justice is a misreading, I believe, of the character of Catholic worship. In both history and contemporary documents, the themes are intertwined. In the Acts of the Apostles, probably written toward the end of the first century, the Christian community on the day of Pentecost, when according to tradition the Holy Spirit came to the community, was described as follows: "They devoted 
themselves to the apostles' teaching and fellowship, to the breaking of the bread and the prayers....All who believed were together and had all things in common; they would sell their possessions and goods and distribute the proceeds to all who had need....they broke bread...with glad and generous hears, praising God and having the goodwill of all the people.” (Acts 2: 41-47)

The first document issued by Vatican II was The Constitution on the Sacred Liturgy. ${ }^{43}$ While noting the "the sacred liturgy is not the Church's only activity," it goes on to say, "Nevertheless, the liturgy is the summit toward which the activity of the Church is directed; it is also the source from which all its power flows." ${ }^{44}$ In the liturgy, the redemption and sanctification of men and women are both remembered and accomplished; the community of disciples is assembled and united; and a moral framework for all of life is taught and exemplified. ${ }^{45}$

The first part of every Sunday liturgy in every parish, following opening hymns and brief prayers, centers on three scripture readings, from the Old Testament the apostolic letters and the gospels. ${ }^{46}$ The gospels are read more or less in order over a three year cycle, thus ensuring that all of Jesus' teachings and actions are presented at some point in the cycle, including of course his acts of charity and his teachings on the poor. A short homily follows the day’s assigned scripture readings. These Sunday homilies are the primary occasions for calling to the attention of Catholics what the Church teaches about doctrine, the virtuous life, morality, charity and politics. ${ }^{47}$

Homilists have a fair amount of discretion over their Sunday preaching, and as far as I know there has been no systematic survey of what they say or how they say it. The official guidance on homilies for America’s Catholic parishes comes from the National 
Conference of Catholic Bishops in the document "Fulfilled in Your Hearing." 48 This document suggests that the task of the preacher is to "speak from the Scriptures to a gathered congregation in such a way that those assembled will be able to worship God in spirit and truth, and then go forth to love and serve the Lord." ${ }^{49}$ Interestingly, it deemphasizes doctrinal instruction and moral exhortation as central focuses of homilies, and continually stresses the importance of helping the faithful to recognize the presence of God in their lives.

A number of guides, and indeed prepared homilies, are available for those who choose to use them. ${ }^{50}$ The ones I have looked at tend to focus on the development of character, the importance of faith, and the performance of personal acts of itness and charity. ${ }^{51}$ Perhaps the most "activist” advice on homilies, and countless examples of actual homilies, come from the project of Walter J. Burghardt SJ on "Preaching the Just Word,” which he describes as "an effort to improve significantly the preaching of justice issues.”, ${ }^{22}$ Burghardt's published homilies, which he offers as examples of ways to achieve this goal, are scriptural, attentive to virtue and character, non-partisan and seldom explicitly political. They often include both statistical and anecdotal descriptions of social and economic problems. Burghardt sees the job of the homilist as helping his listeners "hear the cry of the poor" in their heart and respond consistently with the gospels, which of course contain a good deal of material on compassion and justice for the poor.

The liturgy of the word closes with the communal recitation of an ancient creed followed by a series of short prayers, usually of the form: "For x, we pray to the Lord;" “Lord hear our prayer.” Prayers typically reflecting general concerns for the community 
(for the poor and the sick), current public concerns (for peace in the middle east and northern Ireland; for public officials, that their votes may reflect a respect for life) or parishioners' needs (for Mary Smith as she undergoes chemotherapy).

Most parishes take up a collection between this first part of the liturgy and the second. Sometimes, following the practice of the early Church (and the urgings of at least some contemporary liturgical theologians), the collection is for the poor; usually, however, the collection is for the support of the parish with periodic second collections for various diocesan, papal or charitable activities.

The second part of every Sunday liturgy is the liturgy of the Eucharist, a ritual meal, in which bread and wine are brought to the table, blessed, transformed, broken and distributed to the community in celebration of the death and resurrection of Jesus and of his continued life in the Church. The blessed and transformed bread and wine, now, for Catholics, the body and blood of Jesus, are distributed to the congregation, nearly all of whom typically come forward to receive. Receiving communion both symbolizes and makes real the continuing presence of God in the community and in each individual person's life.

The Eucharistic liturgy is full of the symbols and prayers of community, reflective of the inclusive table fellowship of Jesus. Parishes vary somewhat in their liturgical style for the Eucharist, with some emphasizing more the reenactment by the priest of Jesus' sacrificial death and others emphasizing the shared meal of the community, though both, by virtue of the common rubrics, are intrinsic to the liturgy. Parishes also vary in the extent to which they are and aspire to be inclusive communities. Jesus scandalized his contemporaries by eating and drinking with "tax collectors and sinners," and by 
inviting all manner of people to share his table, together. Contemporary Catholic parishes, being geographically based, are as homo- or heterogeneous as the geographic areas they serve. In addition, some parishes are less welcoming to various groups because of their styles of liturgy; patterns of dress and behavior; or attitudes toward different lifestyles. Others make serious efforts to be inclusive and to be multicultural, and at least at the Eucharistic table to break down divisions of race, class, age and life style.

The liturgy is also full of pointers to the moral life. Scripture readings and homilies tend to be quite explicit in their moral teachings. Prayers emphasize peace, unity, love, charity and gratitude. The liturgy closes with the words, "Go in peace to love and serve the Lord," to which many add, "and one another.” Pastors and parishes vary in their emphases on different aspects of the moral life, especially in the extent to which homilies and prayers are focused on issues of social and economic justice, personal rectitude and acts of charity, individual spiritual development, or sexual morality.

By placing worshippers in the presence of God and bringing God fully to life in them, the liturgy can exercise tremendous power in building community and transforming lives to be full of love and service. ${ }^{53}$ If liturgy is done well and consistently with Vatican II liturgical thinking, it should embody and enhance the communal and justiceoriented teachings of the Church, rather than compete with them. Even if parishes did nothing else, the character of the liturgy would still lead one to expect to see these themes echoed in the lives of Catholics. 


\section{Understanding the Patterns}

Catholic engagement in civic life presents a complicated reality, indeed a puzzle. Official Catholic teachings stress involvement especially on behalf of the poor, through both personal charity and public policy, and the responsibilities of individuals to their communities. The liturgy reinforces these themes. But the practice of Catholic men and women in civic and political life is at best non-distinguishable from that of others and most likely is characterized by lower involvement by Catholics. The life of Catholic parishes varies considerably, but exhibits levels of organization and activity considerably lower than in other tradition.

How do we understand these patterns? I do not believe, as I attempted to show above, that the sacramental character of the Catholic Church is an explanation. Another hypothesis, suggested by Verba et al as an explanation for their findings about low level of civic skill development among Catholics, has to do with size. Catholic parishes are much larger on average than Protestant congregations and assemblies for worship are also much larger, making the development of intimate community more difficult and providing fewer opportunities for individual parishioners to exercise leadership. ${ }^{54}$ On the other hand, it appears from the data that large Protestant congregations manage to solve this problem. Certainly some mega-churches have developed much more extensive programs and ministries, including myriad small groups in which their members can participate. $^{55}$

An alternative explanation has been proposed by Jerome Baggett, on the basis of observational studies of parishes in the Bay Area and the lens of culture production. ${ }^{56}$ 
Baggett's interviews with active parishioners revealed norms of non-judgmentalism, doctrinal independence and avoidance of controversial issues. He argues that:

“(Parish cultures) produce the inability to connect the religious with the civic....By giving pride of place to affective commitment, by normalizing commitments to the parish that are tenuous and segmentary, and by institutionalizing norms whereby parishioners are free (even expected) to disagree with the Church on socio-political issues but not engage with one another on these topics, these parishes inadvertently produce institutional cultures that make it more difficult for members to connect the religious with the political, the private with the public. ${ }^{, 57}$

This analysis is more or less consistent with Alan Wolfe's description of the personalistic and anti-institutional nature of American religion more generally. ${ }^{58}$ But it does not seem to me to fully explain why Catholics appear to be different from adherents to other religious traditions. To explore that question, I suggest that there are structural and organizational features of the American Catholic Church that go a long way toward explaining the patterns that we see..$^{59}$

1. Hierarchical structures.. Notwithstanding the emphasis of Vatican II on the church as the people of God, its hierarchical structure remains an important feature of the Catholic Church. Bishops of dioceses own parish churches and schools, control the assignment of clergy, and prescribe many aspects of parish life. Laity and parish-based clergy often defer to what are perceived to be higher levels in the Church to initiate activities and ministries and are fearful of official sanctions if their initiatives are perceived as inappropriate. This can and does result in passivity in parishes where clergy and laity let it happen. The hierarchical structure of the Church can also result in reluctance on the part of priests or bishops to give up the power they perceive as theirs, or to welcome lay initiatives. ${ }^{60}$ 


\section{Specialization by national and regional structures. Another feature of}

Church structure is the existence of national and regional charitable and political action agencies, independent of parishes and under the control of bishops. Catholic Charities is the largest social services network in the country; it is professional and centralized and seems to feel little need for participation in its ministries by parishioners. ${ }^{61}$ Both Catholic Charities USA and the National Conference of Catholic Bishops have lobbying offices that operate in Washington and in many state capitals. They too rely on professionals to do the work and bishops to make the decisions, independent of the parishes that one might have expected to be their grass roots.

Historically, lay Catholics have been deferential to priests and bishops, and they in turn reinforced attitudes and structures that preserved their power and status. These centralized and differentiated structures have no doubt also increased efficiency, and perhaps effectiveness and the quality of services; certainly the professionalization of social services that occurred in the first half of this century corrected many abuses. But they have also taken a toll, as we have seen, the loss of opportunities for discipleship by Catholics and the loss of much civic energy to the polity.

3. Human resource constraints. Another part of the explanation of Catholic inactivity has to do with a shortage of human resources in parishes, a shortage that is exacerbated by Church rules and traditional practices. Ordained priests, required by Church law to be male and celibate, are central to Catholic practice. Only ordained priests can preside at the Eucharist, administer most sacraments and preach at Eucharistic liturgies. Ordained priests must conduct the daily liturgies which are traditional in 
Catholic practice, and must preside at funeral Masses, wedding Masses and most baptisms.

Since the 1960s, the number of priests has declined dramatically and the average age of priests has increased, while the Catholic population has grown. In the 1950s the ratio of priests to Catholics was about 1:1000; now it is about 1:2000 and is moving rapidly toward 1:3000. Two thirds of Catholic parishes have only one priest. ${ }^{62}$ Parish priests increasingly feel, and indeed are, overworked, and find the sheer demands of the sacraments (Masses, weddings and funerals) leave them little time or energy to improve preaching or parish life. ${ }^{63}$

Traditionally, pastors have controlled everything done in their parishes, either doing it themselves or minutely directing the activities. Only recently and sporadically have priests begun sharing mission and authority with women religious and other lay people. Since the Vatican refuses to entertain the possibility (or even discussion) of a married or female priesthood, this situation is likely to worsen, at least in the medium term. ${ }^{64}$ The short-term answer is clearly much more sharing of ministry with the laity, but Church rules (and in some cases individual bishops) forbid some of the practices (like lay preaching or administering parishes) that could be most helpful. And many priests, especially older priests, have little practice with or inclination toward genuinely participatory parish management. Thus staff constraints in many parishes are serious.

4. Financial constraints. Many parishes are also constrained by financial resources, since Catholics contribute such a low proportion of their income to their parishes. ${ }^{65}$ As noted above, Catholics are more likely than members of other denominations to give nothing or very small amounts of money to their parishes. The 
National Congregations Survey ${ }^{66}$ asked congregational leaders to report both their income and the number of regularly participating adults. Catholic parishes reported income of $\$ 426$ per adult, white conservative or evangelical congregations reported \$1286; white mainline Protestant congregations \$1143; and black Christian congregations $\$ 637$. The implication of this is that parish budgets are also relatively small. ${ }^{67}$

There is in some ways a vicious circle in place, with overworked priests delivering inadequate services which lead to dissatisfaction, lowered attendance and reduced collections, which in turn lead to fewer staff and more overworked priests. In this kind of situation, it is easy to see why energy and capacity are not available for increased parish activity of any kind, including more active engagement with civic life.

5. Constraints on preaching and proclaiming the message. Although there are no studies that I know of on the content of either Sunday homilies or parish discussion groups, personal experience and my examination of the materials and guides that are used in parishes suggest a blandness in discussions of social and political issues. This seems to be especially true for social justice issues, in contrast to the issues of abortion and family life. Homily guides especially seem to emphasize personal morality and avoid pointed political or policy commentary.

This could easily reflect the normal human desire on the part of pastors to please their congregations and not drive people, especially potential contributors, away. The Church is its nature is inclusive, and its parishes are structured to be diverse. The Catholic population is increasingly well-educated, suburban and prosperous; its political attitudes and voting behavior reflect its status. Catholics, like others, may come to 
church primarily to find meaning and reassurance in their lives. Pastors understandably respond to these needs and desires of their congregations.

Another explanation is that sharp preaching that is also appropriate is very hard to do. Translation of the scripturally-rooted social teachings of the Church into specific policies is, as the American bishops recognized in their letters on peace and the economy, complicated and tricky business. Good policy depends not just on right principles but also on empirical assessment and prediction; men and women of good will can reach different conclusions about policy even when they agree on goals and principles. It is arrogant for preachers or Church leaders to assume they can get specific policy right enough to teach authoritatively. It is also inappropriate in pluralist democracies, and ineffective with educated parishioners.

The obvious and common solution to this problem is to preach only on the generalities of the teaching and avoid application to specific issues. This approach has clear appeal. It recognizes the areas in which the Church has clear moral standing, and avoids political controversy. But it poses a different kind of danger. It almost inevitably leads to the formulation of applications of the teaching that represent the minimum requirements and miss their fullness and their demanding and dynamic character. It also lets people off the hook and deprives those members of the congregation who are active in public affairs of the support and guidance of a faith community.

6. Constraints on dialogue. Mature and educated Catholics do not want to be told how to vote, how to manage their businesses or how to structure their life styles. But leaving all these decision purely to individual conscience may well result in missing the point of the Gospel and in too easy slippage into self-interest. The challenge for pastors 
is how to formulate the important moral questions and reflect on them while recognizing legitimate differences of opinion. Creating a community of moral deliberation is not something pastors have necessarily seen as part of their office; the current pope and most bishops do not encourage dissent and debate; nor is moral dialogue something pastors by and large know how to do. Both the general culture of the Church and its practices of pastoral training would have to change for serious moral deliberation to go on in parishes.

7. Challenges to credibility. It is also important to admit that some aspects of recent Catholic history and some structural aspects of the Church make it difficult for pastors to teach credibly on social issues. The hierarchical teaching office lost a good deal of credibility with both lay Catholics and theologians when it reaffirmed traditional teaching on birth control in the face of objections from nearly everyone, including the commission the pope had appointed to study the issue. ${ }^{68}$ Lay Catholics do not obey the teachings on birth control, and pastors by and large neither press nor preach about the issue. The tragedy here is a loss of credibility and perhaps a loss of willingness to speak and to listen on more serious issues. The 2002 crisis around the sexual abuse of minors by priests appears to be an even deeper crisis, shaking the faith of the laity in the credibility and responsible governance of the hierarchy, but also leading to very interesting and potentially important movements for change within the Church.

There is also an issue of the Church's credibility to speak on the fundamental equality of all human persons, given the hierarchical nature of the Church, and especially given the exclusion of women from ordination and from other important offices. Finally, it is more difficult for the Church to speak credibly about deliberation and democratic decision-making when many of its own procedures and practices are anything but; the 
recent scandals and crises that were first exposed in the Archdiocese of Boston and then appeared nationwide are only one dramatic example of this.

\section{Implications}

Catholics make up the single largest religious denomination in the United States, with about 60 million members, and are interesting simply for that reason. But as a case study, the Catholic puzzle also highlights how we need to think about religion in the public square: that religious traditions are not just collections of autonomous individuals whose beliefs and actions can be surveyed and aggregated, but traditions embodied in practice that both shape and are shaped by their members. The Catholic case is particularly interesting in pointing to the importance of official teachings, liturgy and parish life, and the organizational and cultural constraints that interact with all of them.

There are also important implications, I believe, for Catholics. The Church’s role is not to do the business of the state, and I do not want to argue that the Church should change its ways because that would be good for the polity (though I believe that to be true). Instead I believe the Church should be worried because it is not carrying out its mission as effectively as it might, and that to carry out its mission it needs to understand what Catholics actually do and how their parish life and life in the world interact. It also needs to understand how some of the organizational and cultural features of Catholic life impede its ability to serve the vulnerable and proclaim God's kingdom.

The year 2002 was not a good time for the Catholic Church, especially in my own archdiocese of Boston. The failures of closed decision making became painfully and tragically apparent in the clergy sexual abuse scandal. The disillusionment of Catholics 
was apparent in angry sessions in many parishes and poll results indicating that a plurality of Catholics thought their archbishop should resign, as he eventually did.

But Catholics believe that the Holy Spirit works through history in the people of God as whole, not limiting her inspiration to the pope or even the clergy, and making use of the whole spectrum of human knowledge and experience. Despite the tensions and what can only be described as serious and in some cases tragic missteps by the contemporary Church, there is considerable evidence that Catholics love their Church, stick with it and work for change from within. Catholics believe that the Spirit is with the Church until the end of time, nurturing, sanctifying and filling it with life. Her action in the future can be neither predicted nor underestimated. 


\section{APPENDIX}

\section{Regression Results: Without Religious Participation}

\section{Dependent Variable: Informal Social Interaction}

\begin{tabular}{|c|c|c|c|c|c|}
\hline & $\begin{array}{l}\text { Unstandard } \\
\text { Coefficients }\end{array}$ & & $\begin{array}{l}\text { andard } \\
\text { icients }\end{array}$ & $\mathrm{T}$ & Sig. \\
\hline Model & B & Std. Error & Beta & & \\
\hline (Constant) & .714 & .058 & & 12.394 & .000 \\
\hline Catholic & $-3.937 \mathrm{E}-03$ & .032 & -.002 & -.122 & .903 \\
\hline No Religion & $-6.283 E-02$ & .042 & -.029 & -1.505 & 132 \\
\hline If Married & -.198 & .029 & -.139 & -6.929 & .000 \\
\hline Any Kids & $2.018 \mathrm{E}-02$ & .029 & .014 & .686 & .493 \\
\hline If female & 6.622E-02 & .026 & .047 & 2.539 & .011 \\
\hline Age & $-1.284 \mathrm{E}-02$ & .001 & -.307 & -14.574 & .000 \\
\hline $\begin{array}{r}\text { Non-hispan } \\
\text { black }\end{array}$ & -.184 & .042 & -.083 & -4.322 & .000 \\
\hline Asian & -.197 & .088 & -.042 & -2.232 & .026 \\
\hline Hispanic & -.306 & .047 & -.132 & -6.479 & .000 \\
\hline $\begin{array}{r}\text { Education } \\
\text { GT HS }\end{array}$ & $-3.278 \mathrm{E}-02$ & .028 & -.023 & -1.159 & .246 \\
\hline $\begin{array}{r}\text { Low } \\
\text { income }\end{array}$ & $-4.030 \mathrm{E}-02$ & .032 & -.027 & -1.273 & .203 \\
\hline $\begin{array}{r}\text { High } \\
\text { income }\end{array}$ & . 129 & .034 & .076 & 3.787 & .000 \\
\hline $\begin{array}{r}\text { Non-metro } \\
\text { county }\end{array}$ & 2.243E-02 & .030 & .014 & .747 & 455 \\
\hline
\end{tabular}




\section{Dependent Variable: Any Non-religious Volunteering}

\begin{tabular}{|c|c|c|c|c|c|}
\hline & $\begin{array}{l}\text { Unstandard } \\
\text { Coefficients }\end{array}$ & & $\begin{array}{l}\text { andard } \\
\text { icients }\end{array}$ & $\mathrm{T}$ & Sig. \\
\hline Model & B & Std. Error & Beta & & \\
\hline (Constant) & .400 & .041 & & 9.644 & .000 \\
\hline Catholic & $-3.638 E-02$ & .023 & -.032 & -1.566 & .117 \\
\hline No Religion & -.189 & .030 & -.123 & -6.286 & .000 \\
\hline If Married & $1.896 \mathrm{E}-02$ & .021 & .019 & .924 & .356 \\
\hline Any Kids & .106 & .021 & .105 & 5.016 & .000 \\
\hline If female & 6.115E-02 & .019 & .061 & 3.258 & .001 \\
\hline Age & -1.409E-03 & .001 & -.047 & -2.222 & .026 \\
\hline $\begin{array}{r}\text { Non-hispan } \\
\text { black }\end{array}$ & $-5.341 E-02$ & .031 & -.034 & -1.747 & .081 \\
\hline Asian & -.158 & .064 & -.046 & -2.483 & .013 \\
\hline Hispanic & -.116 & .034 & -.070 & -3.422 & .001 \\
\hline $\begin{array}{r}\text { Education } \\
\text { GT HS }\end{array}$ & .230 & .020 & .227 & 11.302 & .000 \\
\hline $\begin{array}{r}\text { Low } \\
\text { income }\end{array}$ & -8.396E-02 & .023 & -.078 & -3.686 & .00 \\
\hline $\begin{array}{r}\text { High } \\
\text { income }\end{array}$ & 5.436E-02 & .024 & .045 & 2.223 & .02 \\
\hline $\begin{array}{l}\text { Non-metro } \\
\text { county }\end{array}$ & $-2.029 \mathrm{E}-03$ & .022 & -.002 & -.094 & .92 \\
\hline
\end{tabular}

\section{Dependent Variable: Giving to Non-religious Charities GT \$100}

\begin{tabular}{|c|c|c|c|c|c|}
\hline & $\begin{array}{l}\text { Unstandard } \\
\text { Coefficients }\end{array}$ & & $\begin{array}{l}\text { andard } \\
\text { icients }\end{array}$ & $\mathrm{T}$ & Sig. \\
\hline Model & B & Std. Error & Beta & & \\
\hline (Constant) & .238 & .042 & & 5.693 & .000 \\
\hline Catholic & $1.964 \mathrm{E}-02$ & .023 & .017 & .841 & .401 \\
\hline No Religion & $-1.450 \mathrm{E}-02$ & .029 & -.010 & -.492 & .623 \\
\hline If Married & 6.776E-02 & .021 & .067 & 3.304 & .001 \\
\hline Any Kids & 1.049E-02 & .021 & .011 & .497 & .619 \\
\hline If female & $-3.117 \mathrm{E}-02$ & .019 & -.031 & -1.656 & .098 \\
\hline Age & 2.632E-03 & .001 & .087 & 4.090 & .000 \\
\hline $\begin{array}{r}\text { Non-hispan } \\
\text { black }\end{array}$ & $-7.744 \mathrm{E}-02$ & .031 & -.049 & -2.534 & .011 \\
\hline Asian & $-7.177 \mathrm{E}-02$ & .065 & -.021 & -1.107 & .268 \\
\hline Hispanic & -.191 & .034 & -.116 & -5.642 & .000 \\
\hline $\begin{array}{r}\text { Education } \\
\text { GT HS }\end{array}$ & .213 & .020 & .212 & 10.501 & .000 \\
\hline $\begin{array}{r}\text { Low } \\
\text { income }\end{array}$ & -.149 & .023 & -.137 & -6.513 & .000 \\
\hline $\begin{array}{r}\text { High } \\
\text { income }\end{array}$ & .166 & .024 & .139 & 6.824 & .000 \\
\hline $\begin{array}{r}\text { Non-metro } \\
\text { county }\end{array}$ & $-9.658 \mathrm{E}-02$ & .022 & -.085 & -4.440 & .000 \\
\hline
\end{tabular}




\section{Regression Results: With Religious Participation (Sample limited to those identified as religious)}

Dependent variable: Social Interaction Scale

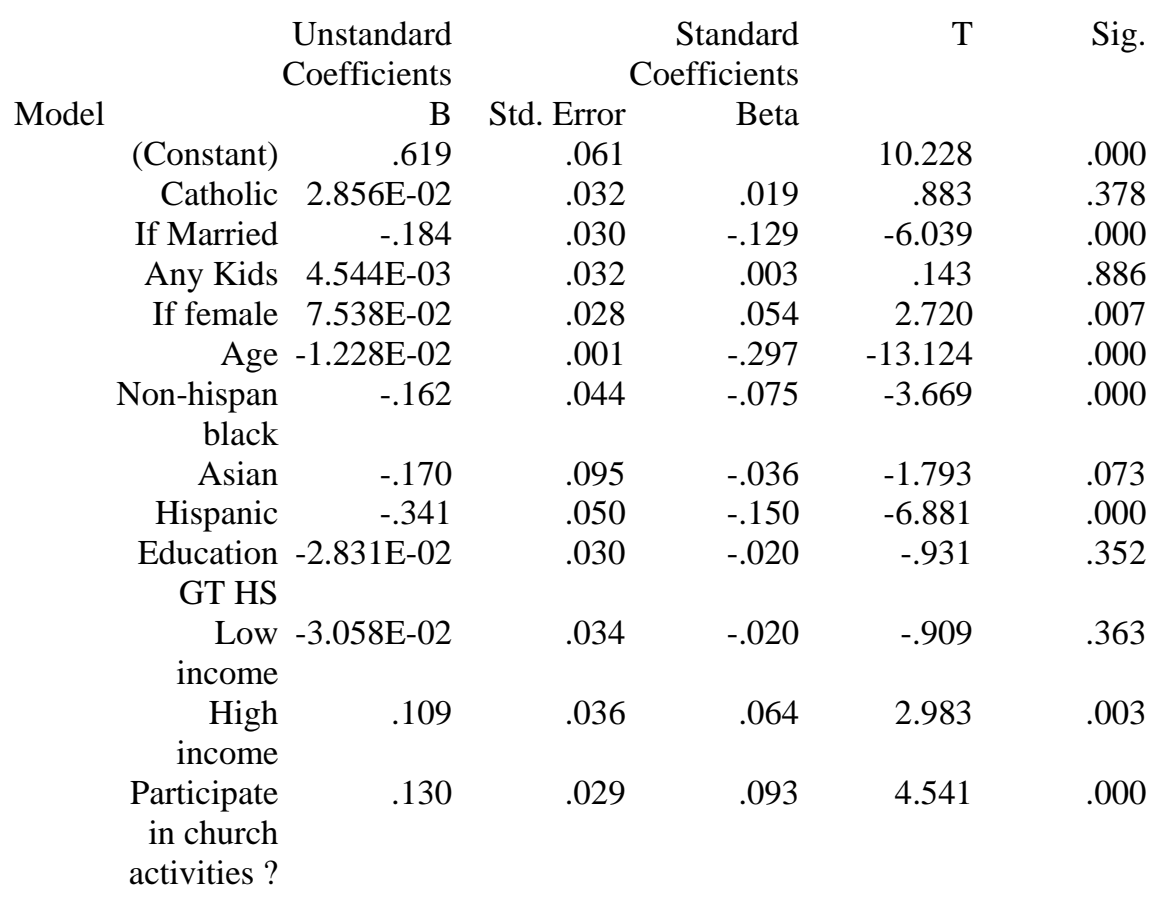

Dependent Variable: Any Non-religious Volunteering

\begin{tabular}{|c|c|c|c|c|c|c|}
\hline \multirow[b]{2}{*}{ Model } & \multicolumn{2}{|r|}{$\begin{array}{r}\text { Unstandard } \\
\text { Coefficients }\end{array}$} & \multicolumn{2}{|c|}{$\begin{array}{r}\text { Standard } \\
\text { Coefficients }\end{array}$} & \multirow[t]{2}{*}{$\mathrm{T}$} & \multirow[t]{2}{*}{ Sig. } \\
\hline & & B & Std. Error & Beta & & \\
\hline 1 & (Constant) & .333 & .042 & & 7.883 & .000 \\
\hline & Catholic & $1.250 \mathrm{E}-03$ & .023 & .001 & .055 & .956 \\
\hline & If Married & $1.066 \mathrm{E}-02$ & .021 & .010 & .501 & .616 \\
\hline & Any Kids & $6.099 \mathrm{E}-02$ & .022 & .061 & 2.746 & .006 \\
\hline & If female & 4.413E-02 & .019 & .044 & 2.278 & .023 \\
\hline & Age & $-1.824 \mathrm{E}-03$ & .001 & -.061 & -2.788 & .005 \\
\hline & $\begin{array}{r}\text { Non-hispan } \\
\text { black }\end{array}$ & $-6.060 \mathrm{E}-02$ & .031 & -.039 & -1.968 & .049 \\
\hline & asian & $-9.660 \mathrm{E}-02$ & .066 & -.028 & -1.457 & .145 \\
\hline & Hispanic & -.109 & .035 & -.067 & -3.144 & .002 \\
\hline & $\begin{array}{r}\text { Education } \\
\text { GT HS }\end{array}$ & .188 & .021 & .186 & 8.860 & .000 \\
\hline & $\begin{array}{r}\text { Low } \\
\text { income }\end{array}$ & $-6.343 E-02$ & .023 & -.059 & -2.700 & .007 \\
\hline & $\begin{array}{r}\text { High } \\
\text { income }\end{array}$ & $6.272 \mathrm{E}-02$ & .026 & .051 & 2.460 & .014 \\
\hline & $\begin{array}{r}\text { Participate } \\
\text { in church } \\
\text { activities? }\end{array}$ & .272 & .020 & .270 & 13.607 & .000 \\
\hline
\end{tabular}




\section{Dependent Variable: Giving to Non-religious Charities GT \$100}

\begin{tabular}{|c|c|c|c|c|c|c|}
\hline \multirow[b]{2}{*}{ Mode } & \multicolumn{2}{|r|}{$\begin{array}{r}\text { Unstandardi } \\
\text { zed } \\
\text { Coefficients }\end{array}$} & \multicolumn{2}{|c|}{$\begin{array}{r}\text { Standardize } \\
\mathrm{d}\end{array}$} & $\mathrm{t}$ & \multirow[t]{2}{*}{ Sig. } \\
\hline & & B & Std. Error & Beta & & \\
\hline 1 & (Constant) & .212 & .045 & & 4.766 & .000 \\
\hline & Catholic & 4.868E-02 & .024 & .045 & 2.064 & .039 \\
\hline & If Married & 4.682E-02 & .022 & .046 & 2.122 & .034 \\
\hline & Any Kids & $-1.391 \mathrm{E}-02$ & .023 & -.014 & -.603 & .546 \\
\hline & If female & $-5.170 \mathrm{E}-02$ & .020 & -.052 & -2.563 & .010 \\
\hline & Age & 1.967E-03 & .001 & .065 & 2.846 & .004 \\
\hline & $\begin{array}{r}\text { Non-hispan } \\
\text { black }\end{array}$ & $-7.933 \mathrm{E}-02$ & .032 & -.051 & -2.482 & .013 \\
\hline & Asian & $-2.435 \mathrm{E}-02$ & .071 & -.007 & -.345 & .730 \\
\hline & Hispanic & -.178 & .036 & -.110 & -4.981 & .000 \\
\hline & $\begin{array}{r}\text { Education } \\
\text { GT HS }\end{array}$ & .184 & .022 & .183 & 8.353 & .000 \\
\hline & $\begin{array}{r}\text { Low } \\
\text { income }\end{array}$ & -.138 & .024 & -.128 & -5.649 & .000 \\
\hline & $\begin{array}{r}\text { High } \\
\text { income }\end{array}$ & .180 & .026 & .149 & 6.835 & .000 \\
\hline & $\begin{array}{l}\text { Participate } \\
\text { in church } \\
\text { activities? }\end{array}$ & .144 & .021 & .144 & 6.934 & .000 \\
\hline
\end{tabular}

\section{Means: Demographic Variables}

\begin{tabular}{|c|c|c|c|c|c|c|c|c|c|c|c|}
\hline Religion & $\begin{array}{c}\text { If } \\
\text { Married }\end{array}$ & Any Kids & If female & Age & NH black & Asian & Hispanic & $\begin{array}{r}\text { Education } \\
\text { GT HS }\end{array}$ & $\begin{array}{r}\text { Low } \\
\text { income }\end{array}$ & $\begin{array}{r}\text { High } \\
\text { income }\end{array}$ & Rural \\
\hline Catholic & .58 & .45 & .50 & 43.40 & .03 & .02 & .27 & .54 & .34 & .23 & .15 \\
\hline Other & .63 & .42 & .55 & 46.58 & .16 & .02 & .04 & .58 & .29 & .20 & .30 \\
\hline $\begin{array}{r}\text { religion } \\
\text { No } \\
\text { religion }\end{array}$ & .43 & 40 & .41 & 37.09 & .09 & .02 & .07 & .57 & .27 & .26 & .24 \\
\hline Total & .59 & .43 & .52 & 44.63 & .11 & .02 & .10 & .57 & .30 & .21 & .25 \\
\hline $\mathrm{N}$ & 2946 & 2958 & 2964 & 2922 & 2934 & 2934 & 2934 & 2946 & 2701 & 2604 & 2964 \\
\hline
\end{tabular}




\section{BIBLIOGRAPHY}

Baggett, Jerome P. (2003). The Catholic Citizen: Perennial Puzzle or Emergent Oxymoron? Berkeley CA, Jesuit School of Theology at Berkeley.

Baldovin SJ, John F. (2003). Bread of Life, Cup of Salvation: Understanding the Mass. Chicago IL, Sheed and Ward/Rowman and Littlefield.

Bergant, Dianne (2000). Preaching the New Lectionary Year C. Collegeville MN, The Liturgical Press.

Bonneau, Mormand (1998). The Sunday Lectionary: Ritual Word, Paschal Shape. Collegeville MN, The Liturgical Press.

Brown, Dorothy M. and Elizabeth McKeown (1997). The Poor Belong to Us: Catholic Charities and American Welfare. Cambridge MA, Harvard University Press.

Burghardt, Walter J. (1996). Preaching the Just Word. New Haven CN, Yale University Press.

Catechism of the Catholic Church (1994). Liguori MO, Liguori Publications.

Chaves, Mark (1998). National Congregations Survey: Data File and Codebook. Tucson AZ, University of Arizona.

Chaves, Mark, Helen Giesel, et al. (2000). Religious Variations in Public Presence: Evidence from the National Congregations Study. Quietly Influential: The Public Role of Mainline Protestantism. Robert Wuthnow and John H. Evans. Berkeley, University of California Press.

Coriden, James A. (1997). The Parish in Catholic Tradition: History, Theology and Canon Law. Mahwah NJ, Paulist Press.

Curran, Charles E. (1999). The Catholic Moral Tradition Today: A Synthesis.

Washington DC, Georgetown University Press.

Donahue SJ, John R. (1993). What Does the Lord Require? A Bibliographical Essay on the Bible and Social Justice. St. Louis MO, The Seminar on Jesuit Spirituality.

Flannery, Austin O.P., Ed. (1996). Vatican Council I I: The Basic Sixteen Documents: Constitutions, Decrees, Declarations. Northport NY, Costello Publishing Co.

Froehle, Bryan T. and Mary L. Gautier (2000). Catholicism USA. Maryknoll NY, Orbis Books. 
Fuechtmann, Thomas B., Ed. (1988). Consistent Ethic of Life. Kansas City MO, Sheed and Ward.

Gaillardetz, Richard R. (1997). Teaching with Authority: A Theology of the Magisterium in the Church. Collegeville MN, The Liturgical Press.

Greeley, Andrew M. (1990). The Catholic Myth: The Behavior and Beliefs of American Catholics. New York NY, Chales Scribner's Sons.

Gula, Richard M., S.S. (1989). Reason Informed by Faith: Foundations of Catholic Morality. Mahwah NJ, Paulist Press.

Hays, Richard B. (1996). The Moral Vision of the New Testament: A Contemporary Introduction to New Testament Ethics. San Francisco CA, The Seabury Press.

Hodgkinson, Virginia A. and Murray S. Weitzman (1996). Giving and Volunteering in the United States. Washington DC, Independent Sector.

Hoge, Dean R., Patrick McNamara, et al. (1997). Plain Talk About Churches and Money. Washington DC, The Alban Institute.

Hoge, Dean R., Charles Zech, et al. (1996). Money Matters: Personal Giving in American Churches. Louisville KY, Westminster John Knox Press.

Hughes, H. Kathleen and Mark R Francis, Eds. (1991). Living No Longer for Ourselves: Liturgy and Justice in the Nineties. Collegeville MN, The Liturgical Press.

Keeler, Robert F. (1997). Parish! New York NY, The Crossroad Publishing Company.

Lectionary for Mass: Introduction (1991). The Liturgy Documents I. Chicago IL, Liturgy Training Publications: 124-164.

Leege, David C. and Paul D. Mueller (2004). How Catholic Is the Catholic Vote? American Catholics and Civic Engagement: A Distinctive Voice. Margaret O'Brien Steinfels. Lanham MD, Sheed and Ward/Rowman and Littlefield.

Lohfink SJ, Norbert F. (1987). Option for the Poor: The Basic Principle of Liberation Theology in the Light of the Bible. N. Richland Hills TX, BIBAL Press.

Manza, Jeff and Nathan Wright (2003). Religion and Political Behavior. The Handbook of the Sociology of Religion. Michele Dillon. Cambridge UK, Cambridge University Press: 297-314.

Massaro SJ, Thomas J. and Thomas A. Shannon, Eds. (2002). American Catholic Social Teaching. Collegeville MN, The Liturgical Press. 
Miller, Donald E. (1997). Reinventing American Protestantism: Christianity in the New Millennium. Berkeley CA, University of California Press.

Murnion, Philip J. and David DeLambo (1999). Parishes and Parish Ministers: A Study of Parish Lay Ministry. New York NY, National Pastoral Life Center: 80.

National Conference of Catholic Bishops (1986). Economic Justice for All: Pastoral Letter on Catholic Social Teaching and the Us Economy. Washington DC, National Conference of Catholic Bishops.

National Conference of Catholic Bishops (1991). Fulfilled in Your Hearing: The Homily in the Sunday Assembly. The Liturgy Documents I. Chicago IL, Liturgical Training Press: $345-376$.

National Conference of Catholic Bishops (2003). Faithful Citizenship: A Catholic Call to Political Responsibility. Washington DC, National Conference of Catholic Bishops.

Oates, Mary J. (1995). The Catholic Philanthropic Tradition in America. Bloomington IN, Indiana University Press.

O'Brien, David J. and Thomas A. Shannon, Eds. (1998). Catholic Social Thought: The Documentary Heritage. Maryknoll NY, Orbis Books`.

Putnam, Robert D. (2000). Bowling Alone: The Collapse and Revival of American Community. New York NY, Simon and Schuster.

Rynne, Xavier (1968). Vatican Council Ii. Maryknoll NY, Orbis Books.

Schaller, Lyle E. (2000). The Very Large Church: New Rules for Leaders. Nashville TN, Abington Press.

Smith, Christian (1998). American Evangelicalism: Embattled and Thriving. Chicago IL, University of Chicago Press.

Spohn, William C. (1995). What Are They Saying About Scripture and Ethics? (Revised Edition). Mahwah NY, Paulist Press.

Spohn, William C. (1999). Go and Do Likewise: Jesus and Ethics. New York NY, Continuum Publishing.

Steinfels, Margaret O'Brien, Ed. (2004). Amcerican Catholics and Civic Engagement: A Distinctive Voice. Lanham MD, Sheed and Ward/Rowman and Littlefield.

Steinfels, Peter (2003). A People Adrift: The Crisis of the Roman Catholic Church in America. New York NY, Simon and Schuster. 
Sullivan S.J., Francis A. (1983). Magisterium: The Teaching Authority in the Catholic Church. Mahwah NJ, Paulist Press.

Tropman, John F. (2002). The Catholic Ethic and the Spirit of Community. Washington DC, Georgetown University Press.

United States Conference of Catholic Bishops (2003). General Instruction of the Roman Missal. Washington DC, United States Catholic Conference.

Vatican Council II (1995). Gaudium Et Spes: Pastoral Constitution on the Church in the Modern World. Vatican Council Ii: The Basic Sixteen Documents. Austin Flannery, O.P. Northport NewYork, Costello Publishing Co.

Vatican Council II (1995). Sacrosanctum Concilium: The Constitution on the Sacred Liturgy. Vatican Council Ii; the Basic Sixteen Documents. O.P. Austin Flannery. Northport NY, Costello Publishing Company: 117-161.

Verba, Sidney, Kay Lehman Schlozman, et al. (1995). Voice and Equality: Civic Voluntarism in American Politics. Cambridge MA, Harvard University Press.

Warren, Mark R. (2001). Dry Bones Rattling: Community Building to Revitalize American Democracy. Princeton NJ, Princeton University Press.

Wilkes, Paul (2001). Excellent Catholic Parishes. Mahwah NJ, Paulist Press.

Wolfe, Alan (1998). One Nation, after All. New York NY, Viking Penguin.

Wolfe, Alan (2003). The Transformation of American Religion: How We Actually Live Our Faith. New York NY, Free Press.

Wuthnow, Robert J. (2002). Beyond Quiet Influence? The Quiet Hand of God: FaithBased Activism and the Public Role of Mainline Protestantism. Robert J. Wuthnow and John H. Evans. Berkeley CA, Univesity of California Press.

Zech, Charles E., Francis J. Butler, et al. (2000). Why Catholics Don't Give...And What Can Be Done About It. Huntington IN, Our Sunday Visitor. 


\section{ENDNOTES}

${ }^{1}$ The question of Catholic participation in the public square has been the topic of recent research and deliberation, exemplified by the Pre Forum sponsored project on American Catholics in the Public Square. Project activities are described at http://www.catholicsinpublicsquare.org/. Major papers have been published in Steinfels, 2004. The examples come both from that collection and from sources cited later in this paper.

${ }^{2}$ Statistics on the Catholic population and on many aspects of Catholic life have been collected in Froehle and Gautier, 2000.

${ }^{3}$ Nancy Ammerman, "Religious Narratives in the Public Square, in Mary Jo Bane, Brent Coffin and Richard Higgins, editors, Taking Faith Seriously. Harvard University Press, 2005, pp. 146-174.

${ }^{4}$ For discussions of the nature of the magisterium see Curran, 1999, Gaillardetz, 1997, Gula, 1989 and especially Sullivan S.J., 1983. Even those considered dissenters, like Curran, hold that there exists "an authoritative teaching role for bishops and pope in the Catholic Church that also involves moral matters.” (Curran, 1999, p. 200.) There is debate over the exercise of the teaching office and over the type of assent that Catholics are required to give to the teachings of the magisterium that are not explicitly defined as infallible, as none of the social teachings are. Lumen Gentium says, "In matters of faith and morals, the bishops speak in the name of Christ and the faithful are to accept their teaching and adhere to it with a religious assent of soul.” (LG n 25.) After carefully examining the Council debates that led to this particular formulation, Sullivan interprets it as meaning that the teaching of the ordinary magisterium (i.e., those teachings not declared a infallible) requires "an honest and sustained effort to overcome any contrary opinion I might have and to achieve a sincere assent of mind to this teaching." (Sullivan, 1983, p. 189.)

${ }^{5}$ Of these documents, the Council documents would probably be considered by all to have the greatest authority, and the documents produced by conferences of bishops to have lesser authority. The major documents have been collected in O'Brien and Shannon, 1998. Major American documents have been collected by Massaro SJ and Shannon, 2002. Recent documents from the American Catholic bishops are available at http://www.usccb.org/ Also important is Catechism of the Catholic Church, 1994.

${ }^{6}$ Gula, 1989, describes three roles of the church: as shaper of moral character, through liturgy and symbol; bearer of moral tradition and moral teachings; and as a community of moral deliberation.

${ }^{7}$ Lumen Gentium, Dogmatic Constitution on the Church, translated in Flannery, 1996. 
${ }^{8}$ Gaudium et Spes, Pastoral Constitution On the Church in the Modern World, translated in Flannery, 1996.

${ }^{9}$ Both of these documents are in Flannery, 1996.

${ }^{10}$ Vatican Council II, 1995, P. 1

11 In O'Brien and Shannon, 1998, chapter 2, p. 294.

12 The social teachings differ in their underlying methodology from the official teachings on sexual ethics and reproduction which rely heavily on concepts of the "natural." The social teachings do appeal to experience and reason assumed to be common to and accessible to all human beings. Consistent with new directions in Christian ethics, the major statements in the social teachings also rely heavily on scripture, not with the methodology of "proof texting" but in at attempt to elicit the deep underlying principles and images. For discussions of methodology, see Gula, 1989; on the uses of scripture as a basis for morality see, for example, Hays, 1996 Spohn, 1995 and Spohn, 1999. On social justice in the Old Testament, see Lohfink SJ, 1987; on social justice in the New Testament see Donahue SJ, 1993.

13 In a very recent letter, National Conference of Catholic Bishops, 2003, the bishops state the themes of Catholic social teaching as follows: Life and the dignity of the human person; Call to family, community and participation; Rights and responsibilities; Option for the poor and vulnerable; Solidarity; Caring for God's creation.

14 The Rev. Eugene Rives of Boston's Ten Point Coalition and political scientist John Diuluio introduced me to the formulation "pro-life, pro-family, pro-poor." They see it, and I agree with them, as powerful language around which Catholics and evangelical Christians might be able to make common cause. It reflects, of course, John Cardinal Bernardin's notion of a "consistent ethic of life.” A number of Bernardin's addresses on this topic, plus responses to them, are collected in Fuechtmann, 1988.

15 Christian Smith's discussion of evangelical attitudes toward social change, in Smith, 1998, is especially interesting in this regard. See also Wolfe, 1998 and Wolfe, 2003.

${ }^{16}$ National Conference of Catholic Bishops, 1986.

17 National Conference of Catholic Bishops, 2003.

18 National Conference of Catholic Bishops, 2003, p. 4

19 National Conference of Catholic Bishops, 2003, p. 3. 
${ }^{20}$ See, for example, the data on different orientations in Nancy Ammerman's paper in this volume, the poll data presented in Froehle and Gautier, 2000, pp. 28-35, and the discussion in Manza and Wright, 2003 and Leege and Mueller, 2004. On the other hand, Tropman, 2002, describes and provides some empirical evidence for a distinctly Catholic ethic.

${ }^{21}$ Civic and political activity, rather than attitudes or voting behavior, are my focus here. The latter are the subjects of a set of interesting papers in Steinfels, 2004.

${ }^{22}$ Hodgkinson and Weitzman, 1996. Appendix D, Table 1, p. D152.

${ }^{23}$ Smith, 1998, Table 2.7, pp. 41-42.

${ }^{24}$ Wuthnow, 2002, Table 15.4, p. 390.

${ }^{25}$ Ammerman, “Religious Narratives.”

${ }^{26}$ Nationally, Catholics are slightly better educated and have slightly higher incomes that other groups. Catholics who identified themselves as Hispanics, who are not as well off, made up about 27 percent of the Catholic respondents to the Social Capital Benchmark Survey. Ammerman's respondents were from two Albuquerque parishes, which were disproportionately Latino. Means on the other demographic variables used in the analysis of the social capital data are presented in the Appendix.

${ }^{27}$ The regression results are presented in the Appendix.

${ }^{28}$ Regression results in the appendix.

29 Putnam, 2000.

${ }^{30}$ Verba, Schlozman and Brady, 1995.

31 This section was written before St. William’s parish was closed in the parish reconfiguration process of the Boston Archdiocese in 2004. I have left the material in the present tense. But St. William's is no more, and has been succeeded by a new parish, Blessed Mother Teresa of Calcutta, which worships in the church of the former St. Margaret's parish.

32 St. William's is the parish in my neighborhood, not in the university community where I work; it is middle and working class rather than elite, and not particularly intellectual or progressive. I am a regular Mass attendee at St. William's, a lector and a member of the Parish Pastoral Council and the Committee on Services to the Poor. I am an occasional consultant to the pastor on financial and other issues. My observations on this parish are thus those of a member, not an objective observer. 
${ }^{33}$ About 150-200 parishioners contribute using envelopes in a given week. If as many people put cash in the collection plate as use envelopes, then about 50 percent of attendees who are perhaps 50-60 percent of members, contribute. The average contribution of envelope users is about $\$ 15$ per week, and the average household income about $\$ 40,000$ (census data suggest that average household income in the tracts making up the parish was about $\$ 35,000$ in 1990), suggesting that even those who use envelopes are contributing less than 2 percent of income.

${ }^{34}$ The history and theology of parishes are clearly explained in Coriden, 1997. Parishes are defined geographically, and are thus somewhat different from the voluntary congregations of other traditions.

${ }^{35}$ Chaves, 1998. It is not clear whether respondents to the NCS would have included funerals and weddings in their count of worship services. They are liturgical celebrations. The average parish probably celebrates one or two a week.

${ }^{36}$ In the Boston archdiocese, decisions about staff assignments, parish consolidations and so on are made largely on the basis of a "sacramental index" which is meant to measure the workload of parishes, more accurately, the workload of priests. The sacramental index is equal to the number of baptisms plus the number of funerals plus twice the number of marriages. This seems to me like a quite odd way to think about parish activity and resources, but I suppose there is a certain logic to it.

${ }^{37}$ Murnion and DeLambo, 1999

${ }^{38}$ Chaves, Giesel and Tsitsos, 2000

${ }^{39}$ IAF is notoriously short on written publications. One helpful one is IAF 50 Years: Organizing for Change, published by the Industrial Areas Foundation in 1990. An excellent recent description is Warren, 2001.

${ }^{40}$ For example, Putnam, 2000 and Warren, 2001..

${ }^{41}$ Keeler, 1997 p. 7.

${ }^{42}$ Keeler, 1997, p. 27. Other lively Catholic parishes are described in Wilkes, 2001

${ }^{43}$ Vatican Council II, 1995. That this document was issued first could reflect the importance that the Council gave to the church as sacrament and mystery. It also reflects however, the pragmatic decision that the council might actually be able to reach agreement on the liturgy. Rynne, 1968

${ }^{44}$ Vatican Council II, 1995, 9 and 10. 
${ }^{45}$ The newest official instructions for celebrating the liturgy are laid out in The General Instruction of the Roman Missal, pronounced, by most priests, "germ" (United States Conference of Catholic Bishops, 2003). A more theological discussion of the liturgy and the most recent changes in the rites is Baldovin SJ, 2003. An excellent discussion of Catholic liturgy as it is practiced and the controversies surrounding it is found in chapter 5 of Steinfels, 2003.

${ }^{46}$ A helpful source on the lectionary is Bonneau, 1998. The official description of the lectionary is found in Lectionary for Mass: Introduction, 1991

${ }^{47}$ Respondents to the National Congregation Study reported an average homily length of 13.5 minutes. Chaves, 1998

${ }^{48}$ National Conference of Catholic Bishops, 1991

${ }^{49}$ National Conference of Catholic Bishops, 1991, 49.

${ }^{50}$ Searching for "homily services" on the web generates a number of sources. A major one is that of Saint Anthony's Messenger, which offers a subscription to "Homily Helps for Sundays," discussed below. The website of the National Catholic Conference for Total Stewardship offers "homily guides," which include extensive quotes and explanations related to the week's scriptures in the areas of "internal spiritual formation" and "exterior action." An interesting irony is that many of these are written by women, who are not, in the Catholic Church, permitted to deliver homilies. Homily services are apparently used often enough that bishops are concerned about them. National Conference of Catholic Bishops, 1991 includes a section on homily services, which disparages their use as not being responsive to local congregations. For example, the Jesuit weekly, America, offers reflections on the week's scripture readings which could serve as the basis for homilies. The monthly Homilitic and Pastoral Review offers scriptural exegesis and suggestions for homilies from a more traditionally doctrinal point of view. "Homily Helps," published weekly and available by subscription from the St. Anthony Messenger Press, include exegeses of the three readings, a suggested purpose and summary for a homily, an "attention getting" story, a number of applications to contemporary life, and a suggestion for transition to the Eucharist. Published volumes that cover the whole lectionary are also available.

${ }^{51}$ For example, Bergant, 2000 suggests as themes for homilies for the fifteenth Sunday in ordinary time, Year C, when the gospel reading is the parable of the Good Samaritan: openness to the unexpected and love of the law. For the Sunday when the parable of the rich man and Lazarus is read, it suggests the themes of covenant responsibility, judgment and the pursuit of righteousness.

${ }^{52}$ Burghardt, 1996. 
${ }^{53}$ The essays in Hughes and Francis, 1991 explore various aspects of this relationship. In her essay, Hughes points out that liturgical reform and a new emphasis on social justice took different paths after Vatican II, and became the concerns of quite different groups of people. The writers in this collection argue that since liturgy and social justice work have the same ultimate goal, they ought to be thought about in a more integrated way.

${ }^{54}$ Verba, Schlozman and Brady, 1995 report that religious participation develops civic and political skills, such as public speaking, planning meetings, organizing events and so on for members of all denominations except Catholics. They hypothesize that the large size and hierarchical structure of Catholic parishes might explain this discrepancy.

${ }^{55}$ Miller, 1997 describes the activities and philosophy of Calvary, Vineyard and Hope Chapel. Schaller, 2000 advises leaders of large evangelical churches on how to structure programs and activities.

${ }^{56}$ Baggett, 2003.

${ }^{57}$ Baggett, 2003, p. 25.

${ }^{58}$ Wolfe, 2003.

${ }^{59}$ Steinfels, 2003 provides an excellent discussion of the current state of American Catholicism, with fine insights on the role of structural features.

${ }^{60}$ The crisis in the church that was generated by revelations in spring 2002 of clergy sexual abuse and hierarchical cover-ups led to the formation of a number of lay groups, most notably Voice of the Faithful, seeking a voice. In many places, these initiatives were discouraged if not forbidden by the hierarchy.

${ }^{61}$ The story of how Catholic Charities centralized and professionalized is well told in Brown and McKeown, 1997. An analogous story about Catholic philanthropy is told by Oates, 1995.

${ }^{62}$ Froehle and Gautier, 2000, pp. 59-60.

${ }^{63}$ Cozzens, 1999, is a poignant and frank review of the problems of the priesthood, by a long time priest.

${ }^{64}$ It is hard to imagine that sheer necessity will not at some point drive the church to at least a married priesthood, though it is hard to predict when that might be.

65 Greeley, 1990, Hoge, Zech, McNamara and Donahue, 1996 and Hoge, McNamara and Zech, 1997. 
${ }^{66}$ Chaves, 1998

${ }^{67}$ Catholic giving has been studied, most notably by Greeley, 1990 and Zech, Butler and Grant, 2000. Greeley argues that Catholic giving has declined steadily since the 1970s, and attributes the decline to lay anger at the hierarchy and especially at the Church's stand on birth control. Zech disputes this explanation, arguing that low giving is more a function of the ways money is raised and managed in the church; e.g., through Sunday envelopes rather than stewardship campaigns. Both agree that disclosure of financial information and lay participation in church governance increase contributions.

${ }^{68}$ Perhaps the most plausible interpretation of why the pope did what he did is that he was convinced that the church, inspired by the Holy Spirit, could not have been in error on such a serious matter for so long, or that the consequences of admitting that the teachings could change would be a serious undermining of the authority of pope and church. For a balanced presentation of this issue see Gula 1989, for a much stronger interpretation see Wills, 2000. 